\title{
KEDUDUKAN QANUN JINAYAT ACEH DALAM SISTEM HUKUM PIDANA NASIONAL INDONESIA
}

\author{
Ridwan Nurdin \\ Fakultas Syariah dan Hukum UIN Ar-Raniry \\ Jl. Syeikh Abdur Rauf Kopelma Darussalam, Banda Aceh, Aceh, 23111 \\ e-mail: ridwannurdin@yahoo.com
}

\begin{abstract}
Abstrak: Aceh justru telah melahirkan sebuah KUHP versi Aceh yang lumrah disebut Qanun Jinayat Aceh pada 2014 silam, di tengah pembicaraan tentang Rancangan Kitab Undang-Undang Hukum Pidana (RKUHP) Nasional. Sebagai bagian dari wilayah Indonesia, keadaan demikian menimbulkan polemik terjadinya perbedaan (dualisme) hukum antara Aceh dan wilayah lain di Indonesia dalam menanggulangi kejahatan. Dinamika pemidanaan itulah yang menjadi fokus dalam artikel ini. Penelitian ini menunjukkan adanya keunikan dalam Qanun Jinayat Aceh yang patut dijadikan stimulus bagi pembangunan hukum pidana nasional. Di samping itu, reorientasi pemidanaan di Aceh patut menjadi agenda lain demi terintegrasinya Aceh ke dalam sistem hukum pidana nasional. Keistimewaan tidak harus dimaknai sebagai pembeda, melainkan penguat bagi kesatuan sistem hukum di mana Qanun Jinayat Aceh merupakan bagian dari sub-sistem hukum pidana tersebut.
\end{abstract}

\begin{abstract}
The Position of Aceh Criminal Code in the Indonesian National Criminal Code System. In the amidst discussions on the National Criminal Code (RKUHP) draft, Aceh has produced a version of Aceh Criminal Code-commonly referred to as Aceh Qanun Jinayat in 2014. As part of the Indonesian territory, such circumstances certainly bring about a lot of polemics. Among the polemics is the legal difference (dualism) between Aceh and other parts of Indonesia in overcoming the crime. This article focuses on the dynamics of the crime. The study shows the uniqueness of the Aceh Qanun Jinayat which should be a stimulus for the development of the national criminal law. In addition, the reorientation of punishment in Aceh should be another agenda for the sake of Aceh integration into the national penal system. This privilege should not be interpreted as a differentiator, but a reinforcement of the unity system where Aceh Qanun Jinayat is a part of sub-system of criminal law.
\end{abstract}

Kata Kunci: Aceh, hukum pidana, qanun, jinayat 


\section{Pendahuluan}

Mengkaji Aceh dari segi hukum pidana menjadi penting. Salah satu argumentasi pentingnya kajian tersebut dikarenakan penerapan hukum pidana di Aceh didasarkan pada pandangan ideologis keagamaan masyarakatnya, yakni agama Islam. Mungkin sebagian orang akan menyangkalnya karena fakta telah ada negara seperti Iran, Arab Saudi dan negara-negara Islam lainnya yang juga menerapkan hukum pidana Islam sebagai hukum pidana positifnya. Tapi, hal itu bisa dibantah dengan mudah karena penerapan hukum pidana Islam di Aceh cakupannya adalah provinsi, bukan negara. Inilah sisi unik yang menjadikan Aceh berbeda dengan daerah lainnya. ${ }^{1}$

Implementasi syariat Islam di Aceh merupakan suatu yang spesial pada masa modern. Otonomi suatu provinsi dalam negara telah membolehkan melaksanakan sub-sistem hukum secara tersendiri. Hal ini merupakan suatu realita bahwa secara empiris syariat Islam di Aceh telah menjadi nilai yang hidup dalam masyarakat Aceh (existing values) selama berabad-abad. Kekuatan lainnya adalah di mana dalam sistem hukum di Indonesia melalui UUD 1945 menyatakan secara tegas tentang kebebasan beragama dalam artian bebas menjalankan ajaran agama bagi pemeluknya.

Selanjutnya, pengungkapan istilah syariat Islam ditemukan dalam UU No. 44/1999 tentang Keistimewaan Aceh pasal 3 \& 4 yang secara jelas menyatakan bahwa apa yang telah didapatkan oleh Aceh merupakan suatu pengakuan Pemerintah Pusat. Juga, kehidupan keagamaan menjadi bagian penting dalam sosialita masyarakat. Tegasnya, pengaturan masalah akan ditetapkan melalui qanun. Hal ini merupakan perintah negara atau UU yang mewadahi keinginan masyarakat.

Posisi syariat dalam UU merupakan suatu pengejewantahan atas hak-hak istimewa yang dimiliki Aceh seperti pelaksanaan syariat Islam, pendidikan dan adat istiadat. Implementasi dari keistimewaan dimaksud telah tertunda selama \pm 40 tahun lamanya karena itu memulai lagi tentang substansi dan bagaimana konsep penerapannya memerlukan perenungan dan logika yang tepat agar tidak merugikan bagi agama Islam sendiri.

Sejak dari awal deklarasi pelaksanaan syariat Islam tantangan dan bahkan keraguan yang dibarengi rasa pesimis karena tiadanya contoh konkret tentang bagaimana menerapkan syariat Islam dalam konteks dunia modern. Dalam posisi ini dipahami bahwa syariat Islam di Aceh adalah ajaran Islam yang telah diatur dengan Qanun. Ruang lingkup pelaksanaan syariat Islam secara jelas dinyatakan dalam Qanun No. 5 tahun 2000 yaitu:

Pasal 5: (1) Untuk mewujudkan keistimewaan Aceh di bidang penyelenggaraan kehidupan beragama, setiap orang atau badan hukum yang berdomisili di daerah berkewajiban menjunjung tinggi pelaksanaan syariat Islam dalam kehidupannya. (2) Pelaksanaan

${ }^{1}$ Danial, "Fikih Mazhab Iran dan Aceh (Analisis Konsep Pemidanaan dalam Hukum Pidana Iran dan Aceh" (Yogyakarta: Sekolah Pascasarjana UGM, 2015), h. 7. 
Syariat Islam sebagaimana yang dimaksud dalam ayat (1), meliputi: a. 'Aqidah; b. Ibadah; c. Mua'malah; d. Akhlak; e. Pendidikan dan dakwah Islamiyah/amar ma'ruf nahi mungkar; f. Baitul Mal; g. Kemasyarakatan; h. Syiar Islam; i. Pembelaan Islam; j. Qadha; k. Jinayat; 1. Munakahat; dan m. Mawaris.

Kondisi di atas kembali diperkuat dengan kehadiran Undang-Undang Nomor 18 Tahun 2001 tentang Otonomi Khusus. Undang-Undang dengan jelas menyatakan bahwa pemberian kesempatan yang lebih luas untuk mengatur dan mengurus rumah tangganya sendiri, termasuk sumber-sumber ekonomi, menggali sumber daya alam dan sumber daya manusia, dan mengaplikasikan syariat Islam dalam kehidupan bermasyarakat. Kesempatan mengatur dan menata kehidupan hukum dengan syariat Islam sebagai ruhnya bersumber pada landasan hukum yang kuat. Karena itu, dapat disebutkan bahwa pelaksanaan syariat Islam di Aceh merupakan perintah Undang-Undang. ${ }^{2}$

Kehadiran Undang-Undang Nomor 11 Tahun 2006 tentang Pemerintahan Aceh (UUPA), kewenangan Aceh dalam melaksanakan keistimewaannya di bidang syariahtermasukjinayat (hukum pidana Islam)—semakin tegas diatur. Perkembangan baru tentang syariat Islam dalam kehidupan masyarakat Aceh, di mana pendekatan formal penting direalisasikan karena hukuman hanya negara yang berhak menerapkannya sekiranya tidak maka kekacauan akan terjadi. Karena itu, penerapan syariat Islam harus diatur negara karena negara memiliki sistem dan aparat. Adalah salah apabila hukuman atas suatu kejahatan dilakukan oleh masyarakat, misalnya, dengan melempari terdakwa, merendam mereka dalam selokan, dan sebagainya. Secara jelas dapat dilihat dalam Pasal 125 UUPA secara lebih rinci telah diatur yaitu melingkupi substansi ajaran Islam (akidah, syariah dan akhlak).

Inilah landasan juridis lahirnya peraturan pidana Islam di Aceh yang lumrah disebut dengan Qanun Jinayat. Pro-kontra terhadap Qanun yang lahir pada 2014 silam ini sudah barang tentu ada. Namun, bagaimanapun kontroversi yang ada, Qanun Jinayat Aceh tetap merupakan produk hukum yang sah dan diakui di Negara Kesatuan Republik Indonesia. ${ }^{3}$ Itu sebabnya, artikel ini hadir bukan untuk mempertanyakan eksistensi yang kiranya sudah jelas persoalannya, melainkan menjadi analisis alternatif dari sekian banyak analisis yang ada. Di sini, dinamika orientasi pemidanaan di Indonesia menjadi objeknya.

Permasalahannya adalah, hukum pidana Islam di Aceh telah menetapkan prinsipprinsip yang tidak seutuhnya sama dengan prinsip-prinsip hukum pidana Indonesia, sebagaimana tidak sepenuhnya pula berbeda dengan prinsip-prinsip tersebut. Perbedaan itu menyebabkan ketidakcocokan di satu sisi, namun juga menjadi pengisi bagi kekosongan hukum

${ }^{2} \mathrm{Al}$ Yasa Abubakar dan Marahalim, Hukum Pidana Islam di Provinsi Nanggroe Aceh Darussalam (Banda Aceh: Dinas Syari'at Islam, 2006), h. 5.

${ }^{3}$ Biasanya Qanun disejajarkan dengan Undang-Undang. Namun, dalam hierarki peraturan perundang-undangan Indonesia ia disejajarkan dengan Peraturan Daerah (Perda). Lihat UndangUndang Nomor 12 Tahun 2011 tentang Peraturan Perundang-undangan. 
pidana nasional di sisi yang lain. Ada orientasi pemidanaan yang tidak statis namun boleh dibilang berlawanan arah. Misalnya, hukuman cambuk di Aceh yang kerap dianggap sebagai balasan ${ }^{4}$ tentu begitu sederhana ketika ia dihadapkan dengan penjara yang memiliki fungsi rehabilitasi dan resosialisasi. Sebab, ketika cambuk tidak memiliki fungsi rehabilitasi dan resosialisasi sama sekali, maka ia hanya akan menjadi hukuman yang tidak berdaya guna dan harus ditinggalkan.

Menyangkut hukuman cambuk, penelitian Muslim Zainuddin, ${ }^{5}$ mengutip pandangan Abdul Qadir Audah, menyatakan bahwa hukuman cambuk mempunyai tujuan penetapannya yaitu untuk memperbaiki keadaan manusia, baik secara kejiwaan maupun lainnya. Karena manusia harus dihindarkan dari perilaku yang mengarah kepada kejahatan dan ketidaknormalan. Justru itu, kaidah hukuman melingkupi lima hal. Pertama, hukuman yang dijatuhkan mencegah setiap orang untuk melakukan tindak pidana sebelum tindak pidana terjadi (preventif). Apabila hukuman itu telah terjadi maka hukuman itu untuk mendidik si pelaku dan mencegah orang lain untuk meniru dan mengikuti per-buatannya. Kedua, batas hukuman adalah untuk kemaslahatan terhadap masyarakat. Sekiranya untuk kemaslahatannya, masyarakat menuntut hukuman diperberat, maka hukuman pun akan diperberat, demikian juga sebaliknya. Sekiranya kemaslahatan masyarakat mengharapkan agar hukuman dapat diperingan, dikurangi atau bahkan dihapus, maka itu pun menjadi pertimbangan dalam penerapan hukum. Ketiga, apabila untuk memelihara kemaslahatan masyarakat dari pelaku kejahatan dan untuk menghilangkan kejahatan tersebut diharuskan untuk menjatuhkan hukuman mati kepada pelaku, maka hal tersebut merupakan suatu keniscayaan untuk dilakukan karena kejahatan tersebut akan hilang dengan hilangnya pelakunya. Keempat, jika telah menghasilkan kemaslahatan individu dan memelihara kemaslahatan masyarakat, maka hukuman telah sesuai dengan yang disyariatkan. Kelima, mendidik pelaku kejahatan bukan dalam artian untuk membalas dendam melainkan untuk perbaikan atas dirinya.

Problematika pemidanaan di Indonesia dengan adanya daerah khusus dan istimewa seperti Aceh harus dibaca lebih utuh dan menyeluruh. Ini masalah yang sangat dinamis dan bukan sekadar hitam-putih. Relasi Aceh dan Indonesia harusnya menjadi sesuatu yang harmonis, relevan, dan saling mengisi. Oleh karena itu, Aceh dan Indonesia harus terbuka dan harus pula dipahami sebagai satu kesatuan, bukan dua hal yang biner. Artinya, ketika Aceh menerapkan suatu prinsip yang melahirkan norma baru, di mana norma itu berbeda sama sekali dengan KUHP dan Undang-Undang Pidana lainnya di Indonesia,

${ }^{4}$ Cambuk sebagai balasan identik dengan teori jawabir yang cenderung melihat sanksi apa adanya. Pelaksanaannya ditujukan untuk suatu ketaatan dan penghapusan dosa (expiation). Lihat Khairil Akbar, Pidana Mati terhadap Penyalahguna Psikotropika dalam Perspektif Teori Pemidanaan Islam: Studi terhadap UU No. 5 Tahun 1997 tentang Psikotropika (Banda Aceh: UIN Ar-Raniry, 2014), h. 53-55.

${ }^{5}$ Muslim Zainuddin, Problematika Hukuman Cambuk di Aceh (Banda Aceh: Dinas Syari'at Islam, 2011), h. 89-90. 
harusnya dimaknai sebagai pengisi atas kekosongan hukum, bukan menjadi sesuatu yang asing dan dipermasalahkan.

Sebagai bukti, eksistensi hukuman pidana Islam pasca penerapan Syariat Islam telah memberikan pengaruh yang signifikan terkait dengan pidana syariat. Penelitian Ferdiansyah tentang efektivitas pelaksanaan hukuman cambuk terhadap pelanggaran syariat Islam di wilayah hukum Kota Banda Aceh yang mengambil sampel dalam kurun waktu 200520007 menyebutkan bahwa adanya penurunan kejahatan terkait pidana syariat dimaksud. Sedangkan Al Yasa Abubakar menyatakan bahwa hukuman cambuk lebih mendekati rasa keadilan masyarakat dalam penerapan hukum. ${ }^{6}$ Selain itu, survei yang penulis lakukan terhadap beberapa kelompok masyarakat terkait kewibawaan Wilayatul Hisbah menunjukkan bahwa masyarakat menaruh harapan akan berlakunya penerapan syariat secara adil dan transparan dalam bingkai sistem hukum. Penelitian ini menjawab dua pertanyaan dari permasalahan yang telah diuraikan di atas, yaitu bagaimana posisi atau kedudukan hukum pidana Islam di Aceh (Qanun Jinayat) dalam sistem hukum pidana Indonesia, dan bagaimana orientasi pemidanaan dalam sistem hukum Indonesia jika dihubungkan dengan pelaksanaan syariat Islam di Aceh, khususnya di bidang jinayat atau hukum pidana Islam.

\section{Metode Penelitian}

Syariat Islam bersumberkan pada al-Qur'an, Sunnah Nabi SAW. dan pendapat para ulama yang terkandung dalam kitab-kitab fikih. Dalam penerapannya memerlukan suatu kepastian atas pandangan para ulama tersebut karena fikih penuh dengan khazanah ilmiah dengan diskusi dan kaya argumentasi yang sangat variatif. Dalam konteks syariat Islam di Aceh menghadapi banyak pilihan pendapat. Dalam posisi ini pilihan dijatuhkan bukan pada suatu kebenaran karena fikih bersifat relatif. Jelasnya, pandangan fikih bukanlah kewajiban suatu diambil melainkan sebagai pandangan karena syariat Islam di Aceh berorientasi ke masa depan bukan kebelakang. Namun tidak meninggal atau mengabaikan pandangan yang telah eksis.

Selain kerangka di atas, syariat Islam berlaku dalam suatu bingkai hukum artinya syariat Islam diterapkan pada suatu ranah di mana sistem hukumnya telah eksis. Sistem hukum yang berlaku di Indonesia adalah sistem hukum kontinental karena warisan dan pengaruh penjajahan Belanda. Namun sistem dimaksud telah mengalami perubahan yang signifikan karena penyesuaian telah dilakukan agar sejalan dengan alam Indonesia merdeka. Lahirnya berbagai Undang-Undang adalah satu indikasi bahwa sistem hukum Indonesia sedang mengarah pada jati dirinya sebagai suatu negara yang merdeka.

Penelitian ini merupakan penelitian hukum yang bersifat kepustakaan di mana sumber datanya berasal dari Buku, Undang-Undang, peraturan dan lainnya yang terkait. Selain itu, penelitan ini dilakukan dengan menganalisis teks-teks hukum baik hukum

'Ibid., h. 92-93. 
jinayat (Qanun jinayat) maupun hukum pidana Islam. Karena itu penelitian ini mengunakan pendekatan kualitatif. ${ }^{7}$ Ruang lingkup penelitian ini adalah Qanun jinayat yaitu ajaran hukum yang bersumber dari hukum Islam dan saat ini sedang diterapkan di Aceh. Sedangkan variabel lainnya yaitu hukum pidana nasional yang berlaku secara nasional. Penelusuran kedua variabel ini memberikan manfaat bagi pengembangan hukum pidana nasional ke depan karena hukum jinayat adalah hukum yang bersumber dari Islam, di mana ajaran Islam menjadi praktik mayoritas bangsa Indonesia.

Qanun dalam penelitian ini adalah suatu peraturan daerah Aceh yang dihasilkan secara bersama dengan prosedur yang tepat antara DPR Aceh (DPRD Tk 1) dengan Pemerintah Aceh (Gubernur). Qanun telah banyak dihasilkan sedangkan Qanun tentang syariat Islam masih terbatas. Sedangkan pada penelitian ini adalah Qanun Jinayat yaitu Qanun Nomor 6 Tahun 2014 tentang Hukum Jinayat dengan deskripsi sebagai berikut: terdiri dari 10 BAB dan 74 Pasal. Qanun Hukum Acara Jinayat yaitu Qanun Nomor 7 Tahun 2013 tentang Hukum Acara Jinayat, dengan deskripsi sebagai berikut: terdiri dari 23 BAB dan 286 Pasal. Hubungan antara posisi Qanun dan Hukum Nasional dibahas dengan metode deskriptif analisis di mana keduanya dipaparkan dalam konteks relasi hukum yang eksis dalam sistem hukum di Indonesia.

\section{Hasil dan Pembahasan}

\section{Sistem Hukum Nasional Indonesia}

Sebelum jauh menjawab dua masalah tersebut di atas, pada bagian ini diulas sekilas tentang sistem hukum Nasional. Hal ini penting dikemukakan supaya semakin terang perkara yang sedang kita bahas, terutama yang berkaitan dengan kedudukan Qanun Jinayat. Secara berurut didefiniskan terlebih dahulu apa itu sistem, sistem hukum, dan kemudian baru diuraikan bagaimana sistem hukum Indonesia itu.

Secara bahasa, sistem merujuk pada arti seperangkat unsur yang secara teratur saling berkaitan sehingga membentuk suatu totalitas. ${ }^{8}$ Selain itu, sistem dapat pula diartikan sebagai susunan yang teratur dari pandangan, teori, asas, dan sebagainya. ${ }^{9}$ Dengan demikian, sistem (dalam bahasa Yunani: sistema) dapat dimaklumi sebagai satu kesatuan yang memiliki dan terdiri dari komponen-komponen atau sub-subsistem yang banyak jumlahnya, saling berinteraksi, terbuka, hierarkis, dan bertujuan. ${ }^{10}$ Definisi demikian menegaskan bahwa sistem memiliki beberapa fitur ${ }^{11}$ yang kemudian disebut sebagai fitur sistem.

${ }^{7}$ Lexy J. Moleong, Metodologi Penelitian Kualitatif (Bandung: Rosdakarya, 2000), h. 1-6. 8http://kbbi.web.id/sistem, diakses pada Kamis, 15 Februari 2018.

${ }^{9}$ Ibid.

${ }^{10}$ Jasser Audah, Membumikan Hukum Islam Melalui Maqashid Syariah, terj. Rosidin dan Ali Abd el-Mun'im (Bandung: Mizan, 2015), h. 61.

${ }^{11}$ Jasser Audah mengutip teori sistemnya Bartalanffy menyebutkan bahwa sejumlah fitur 
Jika dikaitkan dengan hukum, maka gabungan kata sistem dan hukum dapat diartikan sebagai satu kesatuan utuh yang terdiri dari beberapa sub-bidang hukum di mana unsurunsurnya saling berhubungan satu dengan yang lain. Kesemua unsur-unsur hukum itu perlu bekerja sama menurut tata dan pola yang ada. ${ }^{12}$ Pada dasarnya, hukum itu sendiri merupakan suatu sistem. Wiener-sebagaimana dikutip oleh Netti Endrawati-mendefinisikan hukum sebagai suatu sistem pengawasan perilaku (ethical control) yang diterapkan terhadap sistem komunikasi. ${ }^{13}$ Jadi, selain hukum itu memiliki sistem, hukum itu sendiri adalah sebuah sistem. Pada dasarnya, segala sesuatu memang dapat dikatakan sebagai sistem menurut ukurannya masing-masing. Misalnya hukum pidana, sekalipun ia bagian dari hukum, hukum pidana itu sendiri merupakan sebuah sistem yang lebih kecil dari hukum.

Jika ditanyakan, ${ }^{14}$ apakah sistem hukum Nasional Indonesia merupakan sistem terbuka atau tertutup, jawabnya adalah sistem terbuka. ${ }^{15}$ Mekanisme uji materi Perda/Qanun terhadap Undang-undang atau judicial review Undang-Undang terhadap Undang-Undang Dasar adalah bentuk dari keterbukaan bahwa sistem hukum Indonesia menerima perubahan. Tidak hanya itu, mekanisme legislative review juga bukti lain dari keterbukaan itu. Artinya, sistem hukum Nasional Indonesia menerima perkembangan zaman dan hal itu sudah banyak dibuktikan. Hanya saja, dalam hal hukum pidana, KUHP adalah kondisi yang patut disesalkan karena begitu berlarut-larut pembahasannya. Hingga kini, KUHP Nasional masih merupakan produk Belanda yang di negara asalnya telah berubah dan tidak berlaku lagi.

Sistem hukum Nasional yang sedang dibicarakan ini dapat disederhanakan sebagai satu kesatuan hukum yang utuh di mana segala bidang hukum bekerja saling menopang, memiliki hierarki dan bertujuan. Kesemua sub-sistem hukum Nasional bekerja di atas prinsip yang tertuang dalam UUD. Prinsip dan sumber dari segala sumber hukum Nasional itu sendiri adalah Pancasila. Lima prinsip dasar itulah yang seharusnya menjiwai segala jenis dan tingkatan peraturan di Indonesia. Sistem hukum Nasional lebih identik kepada rumpun atau tradisi hukum Eropa Kontinental atau Civil Law. Sekalipun mengenal hukum adat,

sistem itu adalah: holisme, bertujuan, saling mempengaruhi (interrelationship), memiliki Input dan output, transformatif, regulatif, hierarkis, diferensiasi, ekuifinalitas dan multifinalitas, dan entropi. Ibid., h. 72-73.

${ }^{12}$ Fajar Nurhardianto, "Sistem Hukum dan Posisi Hukum Indonesia," dalam Jurnal TAPIs, Vol. 11. No. 1 Januari-Juni 2015, h. 35.

${ }^{13}$ Netti Endrawati, "Sistem Hukum dan Pembangunan Hukum," dalam Wastu, Vol. Khusus, Desember 2007, h. 43.

${ }^{14}$ Ada beberapa klasifikasi jenis sistem yang di antaranya adalah terbuka dan tertutup, deterministik dan probabilistik, serta abstrak dan fisik. Rusli Muhammad, meterinya diambil dari slide mata kuliah Sistem Peradilan Pidana, PPs Fakultas Hukum Universitas Islam Indonesia, 2016.

${ }^{15}$ Rusli Muhammad berkata, disebut terbuka karena sistem hukum Indonesia membuka diri terhadap perkembangan yang terjadi dalam lingkungan masyarakat, baik berhubungan dengan perkembangan ilmu pengetahuan, terutama yang berkaitan dengan ide-ide atau ajaranajaran dasar atau teori-teori hukum termasuk pula perkembangan di bidang-bidang lainnya. Ibid. 
hukum tertulis berupa peraturan perundang-undangan lebih mengikat sifatnya di negara yang besar ini.

Nurul Qamar mengutip klasifikasi tradisi hukum dunia yang dikemukakan oleh M. Fuady yang mengelompokkan bahwa ada lima tradisi hukum, yaitu: ${ }^{16}$ hukum yang berlaku di Eropa daratan (Hukum Eropa Kontinental), hukum yang berlaku di Inggris (Hukum Anglo Saxon), hukum yang berlaku di Rusia dan bekas Uni Soviet (Hukum Sosialis), hukum yang berlaku di wilayah tertentu (adat/hukum kedaerahan), dan hukum yang berdasarkan ajaran agama (hukum keagamaan). Di samping itu, Qamar juga mengutip klasifikasi lain yang hampir sama dengan M. Fuady, yakni teorinya Marc Ance ${ }^{17}$ sebagai berikut: Civil Law System, Common Law System, Middle East System, Far East System, dan Socialist Law.

Setelah mengemukakan dua pandangan di atas, Nurul Qamar menambahkan bahwa dalam perkembangannya, sistem hukum itu kemudian bercampur. Karenanya harus ditambah satu keluarga hukum lagi, yaitu keluarga atau rumpun hukum campuran. Amatan kami menunjukkan bahwa Indonesia tidak sepenuhnya civil law, tidak pula menganut hukum adat yang sangat beragam, atau hukum Islam semata. Hanya saja, ada satu kecenderungan bahwa semua model hukum itu mengarah kepada formalisasi. Artinya, sistem hukum Nasional mengenal hukum lokal dengan Perdanya, serta hukum Islam dengan Perda/Qanun dan Undang-Undangnya.

Undang-Undang Nomor 1 Tahun 1974 tentang Perkawinan misalnya. Undang-Undang a quo mau tidak mau adalah Undang-Undang yang kental dengan nuansa keislaman. Selain itu, ada Intruksi Presiden Nomor 1 Tahun 1991 tentang Kompilasi Hukum Islam. Kedua peraturan tersebut merupakan contoh konkrit di mana hukum Islam diterapkan dan telah menjadi hukum yang hidup dalam masyarakat Indonesia. Peraturan itu juga dikeluarkan oleh lembaga negara yang sah sehingga harus ditaati. Selain mengakomodir hukum Islam, ada sekian banyak konvensi internasional nyatanya juga diratifikasi oleh Indonesia, terutama yang berkaitan dengan Hak Asasi Manusia. Pada akhirnya, keterbukaan memang mengharuskan kita untuk bercampur dan saling mempengaruhi. Hukum nasional Indonesia dengan begitu dapat disebut sebagai sistem hukum campuran jika merujuk pada klasifikasi yang dikemukakan oleh Nurul Qamar di atas.

Percampuran itu kadang terjadi pada level Undang-Undang, terkadang juga terjadi pada level Perda/Qanun. Qanun Aceh adalah contoh di mana hukum Nasional Indonesia sudah sedemikian bercampur dan dipengruhi oleh hukum Islam. Hal ini diakui dan mendapat legitimasi dari Undang-Undang Nomor 11 Tahun 2006 tentang Pemerintah Aceh itu sendiri. Bagaimanapun ketercampuran suatu produk peraturan perundang-undangan di Indonesia adalah keragaman dalam kesatuan. Salah satunya berlaku di Aceh di mana Aceh merupakan

\footnotetext{
h. 14-15.

${ }^{16}$ Nurul Qamar, Perbandingan Sistem Hukum dan Peradilan (Makasar: Pustaka Refleksi, 2010),

${ }^{17}$ Marc Ancel mendasarkan klasifikasinya pada asal usul dan sejarah perkembangan hukum. Ibid.
} 
MIQOT Vol. XLII No. 2 Juli-Desember 2018

bagian dari Negara Kesatuan Republik Indonesia karena itu hukumnya merupakan bagian dari sistem hukum Nasional.

\section{Kedudukan Qanun Jinayat Aceh dalam Hukum Islam dan Nasional}

Qanun sebagai salah satu bentuk peraturan perundang-undangan di Indonesia bukanlah barang baru. Khususnya di Aceh, Qanun sudah dikenal sejak lama. Salah satu naskah yang dapat dirujuk adalah tulisan dari Tengku di Mulek pada tahun 1257 yang berjudul Qanun Syara' Kerajaan Aceh. ${ }^{18}$ Al Yasa' Abu Bakar sebagaimana dikutip oleh Ahyar menjelaskan bahwa menurut Liaw Yock Fang istilah Qanun semakna dengan adat dan biasa digunakan untuk membedakan antara hukum yang tertuang di dalam fikih dan hukum yang tertera dalam adat. ${ }^{19}$ Untuk konteks sekarang dan khusus di Aceh, Qanun berdasarkan UUPAnya adalah peraturan perundang-undangan sejenis peraturan daerah yang mengatur tentang penyelenggaraan pemerintahan Aceh dan kehidupan masyarakat Aceh. ${ }^{20}$

Definisi demikian tidak lumrah sebenarnya. Qanun ${ }^{21}$ pada level negara biasanya setara dengan Undang-Undang. Secara bahasa, Qanun memang berarti Undang-Undang. Menurut Jasser Audah, Qanun merupakan hukum positif yang dikonstruksi dari fikih dan 'urf. Istilah Qanun biasanya sering dipandang sinonim dengan terma syariah (syariah), fikih (fiqh), dan adat istiadat ('urf). Pada dasarnya ketiga istilah ini memiliki perbedaan yang mendasar. Syariah (syarî́ah) merupakan terma yang mewakili sisi ketuhanan dalam hukum Islam, sementara fikih (fiqh) merepresentasikan sisi kognitif hukum Islam, yaitu sesuatu yang digali dari nash dan tentu saja merupakan hasil kontruksi ijtihad para ahli hukum (fuqahâ'/faqih). Kekaburan batas antara fiqh dan syar'îah mengakibatkan klaimklaim 'kesucian' terhadap hasil ijtihad hukum yang dilakukan oleh manusia yang pada tataran berikutnya akan menyebabkan timbulnya kekerasan atas tuduhan sesat dan bidah. ${ }^{22}$ Sedangkan Qanun dan 'urf masing-masing merepresentasikan sistem perundang-undangan spesifik dan adat istiadat.

Penjelasan demikian menempatkan Qanun sama sekali bukan hukum Islam yang memiliki dimensi ketuhanan (bukan syariat) di mata Audah. Namun, pada kenyataannya

${ }^{18}$ Ahyar Ari Gayo, "Aspek Hukum Pelaksanaan Qanun Jinayat di Provinsi Aceh," dalam Jurnal Penelitian Hukum de Jure, Volu. 17, No. 2, Juni 2017, h. 137.

${ }^{19}$ Ibid.

${ }^{20}$ Pasal 1 Ayat (21) Undang-Undang Nomor 11 Tahun 2006 tentang Pemerintahan Aceh. Lembaran Negara Republik Indonesia Nomor 62 Tahun 2006.

${ }^{21}$ Qanun dalam Kamus Besar Bahasa Indonesia ditulis dengan huruf " $K$ ", yaitu Kanun, artinya: Undang-Undang, peraturan, kitab undang-undang, hukum dan kaidah. Lihat Pusat Pembinaan dan Pengembangan Bahasa Departemen Pendidikan dan Kebudayaan, Kamus Besar Bahasa Indonesia (Jakarta: Balai Pustaka, t.t.), h. 442. Adapun pengertian Qanun menurut kamus Bahasa Arab adalah: Undang-Undang, kebiasaan atau adat. Lihat Mahmud Yunus, Kamus Arab-Indonesia (Jakarta: Hidakarya Agung, 1989), h. 357.

${ }^{22}$ Audah, Membumikan Hukum Islam, h. 322. 
terma syariat justru dikait-kaitkan dengan Qanun di Aceh. Qanun Jinayat Aceh dibahasakan bahkan oleh Undang-Undang sebagai Qanun yang berisikan syariat Islam. ${ }^{23} \mathrm{Hal}$ ini terbukti dengan dimasukkannya jarîmah dan 'uqûbât hudûd di dalam Qanun. Hudûd dalam Qanun Jinayat Aceh—sebagaimana dikatakan Syahrizal—merupakan aturan yang diadopsi apa adanya dari nash dan dituangkan ke dalam Qanun. ${ }^{24}$ Klaim demikian tentu berbahaya dan bisa disebut sebagai klaim 'kesucian'. Syahrizal dengan kata lain menempatkan Qanun dalam dua dimensi, yaitu dimensi ketuhanan dengan aturan $\underline{h} u d u \hat{d}$ nya, dan dimensi kemanusiaan dengan aturan ta'zîrnya.

Jadi, apa yang diteorikan dan diberi garis batas yang sedemikian jelas oleh Jasser Audah tidak berlaku begitu saja untuk Aceh. Aceh memiliki konteksnya sendiri. ${ }^{25}$ Sedangkan apa yang digambarkan oleh Jasser Audah lebih kepada konsep atau teori yang berada di ranah idealita, bukan sebuah realitas. Qanun Jinayat Aceh sendiri merupakan fakta riil keberlakukan hukum pidana Islam di era negara bangsa yang unik. Dilihat bahwa Qanun Jinayat Aceh di sini lebih digambarkan sebagai hukum yang dikonstruksi dari syariat (alQur'an dan Sunah), fiqh dan 'urf.

Qanun (dalam hal ini Qanun Jinayat) diposisikan oleh Jasser Audah dan bagaimana pula untuk konteks Aceh sepanjang amatan penulis bahwa dimensi ketuhanan pada Qanun sama dengan dimensi Ketuhanan pada Sunah Rasul. Memang, sebagian orang menempatkan Sunah seluruhnya masuk dalam kategori syariat. Namun, mengikuti apa yang diajukan oleh Jasser Audah, sebagaian Sunah memang harus keluar dari dimensi ketuhanan (syariat). Hanya saja, Sunah tidak sama sekali terpengaruh, justru ia mempengaruhi lahirnya fikih. Sedangkan Qanun, selain memiliki norma yang diadopsi apa adanya dari syariat, nyatanya juga terpengaruhi oleh fiqh dan 'urf.

Qanun dalam posisinya yang lain, yakni dalam perspektif sistem hukum Nasional Indonesia merupakan bagian dari sistem perundang-undangan Indonesia. Menurut UndangUndang Nomor 12 tahun 2011, kedudukan Qanun Jinayat Aceh berada pada posisi keenam atau selevel dengan Peraturan Daerah Provinsi. Artinya, Qanun Jinayat Aceh selevel dengan Perda di daerah lain sebagaimana telah disinggung di awal. Di atas Qanun ada Perpres, PP, UU/Perppu, TAP MPR, dan terakhir UUD 1945. Jadi, Qanun, selain merupakan Perda Provinsi Aceh, ia juga merupakan bagian dari syariat Islam yang dilegislasi dalam bentuk Qanun oleh DPRA dan disetujui oleh Gubernur Aceh.

${ }^{23}$ Lihat, Pasal 235 Ayat 2 Undang-Undang Nomor 11 Tahun 2006 tentang Pemerintahan Aceh. Lembaran Negara Republik Indonesia Nomor 62 Tahun 2006.

${ }^{24}$ Syahrizal Abbas, Maqashid al-Syariah dalam Qanun Jinayah di Aceh (Banda Aceh: Dinas Syari'at Islam, 2015), h. 31.

${ }^{25}$ Danial, seorang dosen lulusan UGM berhasil mempertahankan disertasinya yang pada kesimpulannya menyatakan bahwa praktik dan sistem pemidanaan di Aceh memiliki konteks yang relatif berbeda dengan Iran (beliau melakukan komparasi terhadap negara Iran). Karena hal tersebut maka Qanun Jinayah Aceh dapat disebut sebagai fikih mazhab Aceh. Lihat Danial, Fikih Mazhab Iran dan Aceh. 
Qanun Jinayat Aceh memang harus dilihat dan dijelaskan dari dua perspektif di atas. Di satu pihak ia merupakan bagian dari sistem hukum Islam, sedang di pihak lain ia merupakan bagian dari sistem hukum Indonesia. Dengan kata lain, Qanun Jinayat Aceh dapatlah disebut sebagai hukum Islam yang dipositifkan, yakni hukum Islam yang konstruksinya digali dari syariat (al-Qur'an dan Sunnah), fiqh dan 'urf lalu dilegislasi menjadi Qanun oleh Dewan Perwakilan Rakyat Aceh dan disetujui oleh Gubernur Aceh. Karena Qanun Jinayat Aceh dipandang sebagai bagian dari upaya penerapan hukum Islam, maka Qanun Jinayat harus dilihat sebagai bagian dari sub-bidang hukum Islam dan tergolong dalam sistem hukum Islam. Selain posisinya yang demikian, Qanun Jinayat Aceh juga merupakan bagian dari sistem perundang-undangan Indonesia yang diakui melalui UU Nomor 12 Tahun 2011 Tentang Pembentukan Peraturan Perundang-undangan.

Namun, tidaklah semua Qanun Aceh merupakan bagian dari syariat yang oleh UndangUndang disebut istimewa dan khusus. Misalnya di bidang penyelenggaraan Pemilu. Qanun Aceh mengenai Pemilu jelas bukan merupakan bagian dari syariat Islam sehingga harus dibaca sebagai bagian dari subsistem hukum Nasional semata. Bahkan, Qanun Aceh yang masuk ke dalam kelompok istimewa sekalipun, belum tentu merupakan bagian dari sub sistem hukum Islam. Dapat disimpulkan, seluruh Qanun Aceh merupakan bagian dari subsistem hukum Nasional, namun hanya sebagiannya yang dapat dikelompokkan sebagai bagian dari sistem hukum Islam. Adapun yang diklasifikasikan sebagai Qanun-Qanun Syariat, maka ia harus dilihat dan dianggap sebagai produk hukum yang berada di dua sistem hukum, Islam dan Indonesia.

Sebelum lolos dari pertimbangan agama, Qanun Jinayat Aceh belum dapat dilegislasi karena ia merupakan hukum Islam. Jadi, harus clear terlebih dahulu polemik keislamannya, baru kemudian dibicarakan proses legislasinya. Hanya saja, polemik keislaman tidak dapat diuji setelah dipositifkan. Ketika Qanun Jinayat Aceh diuji materi ke Mahkamah Agung, sebenarnya yang diuji adalah kesesuaiannya terhadap Undang-Undang di atasnya. Sementara kesesuaiannya terhadap hukum Islam hanya merupakan perdebatan yang abstrak dan hanya mungkin terjadi sebelum Qanun itu dilegislasi (dalam naskah akademik) dan pada sidang DPRA (baik dalam proses taqnîn, atau ketika hendak diuji (legislative review). Tentu keadaan ini menjadi titik lemah terutama dalam upaya menerapkan hukum Islam yang objektif dan murni. Kesesuaian Qanun Jinayat terhadap prinsip-prinsip keislaman harus masuk ke dalam wilayah yang konkret, yaitu dengan menjadikannya sebagai objek perdebatan dalam sidang uji materi di Mahkamah Agung.

\section{Hukum Acara dalam Qanun Jinayat Aceh}

Sebagai bagian dari sistem perundang-undangan Indonesia, Qanun Jinayat Aceh hadir untuk melengkapi apa-apa yang belum diatur dalam hukum pidana nasional. Terkadang, Qanun Jinayat Aceh bahkan menghendaki norma yang relatif berbeda dengan KUHP dan Undang-Undang pidana nasional lainnya. Semangat formalisasi syariat Islam di Aceh tidak 
dapat dipungkiri memang untuk menjadikan Aceh berbeda dengan propinsi lain di Indonesia. Itu sebabnya dalam perkara zina (misalnya), Aceh punya definisinya sendiri. ${ }^{26}$ Atau dalam masalah khamr (minuman keras), Aceh juga punya ukuran tersendiri. Untuk pelecehan seksual, Aceh menetapkan sanksi yang relatif lebih berat dibanding KUHP. Sementara untuk perilaku seperti lesbian dan gay, Aceh tidak sekadar melarang, juga menetapkan sanksi ta'zîr yang berat.

Qanun Jinayat itu sendiri awalnya merupakan Qanun yang terpisah-pisah. Kini, semua jenis jarîmah dan 'uqûbâtnya dikodifikasi ke dalam satu Qanun, bahkan bertambah ${ }^{27}$ secara signifikan jarîmah dan 'uqubatnya. ${ }^{28}$ Pasal 3 Ayat 2 Qanun Jinayat Aceh menyebutkan bahwa Qanun ini hanya mengatur 10 jenis jarîmah (delik) dengan variannya masing-masing. Kesepuluh jarîmah atau tindak pidana itu adalah: khamr; maisir; khalwat; ikhtilâth; zina; pelecehan seksual; pemerkosaan; qadzaf; liwath; dan musâhaqah. Khalwat, pelecehan seksual, (khamr) minuman keras, (maisir) judi, dan pemerkosaan memiliki kesamaan dengan KUHP. Perbedaannya lebih kepada jenis dan bentuk sanksi saja. Sementara zina berbeda secara definisi (perbuatannya) dan hukumannya. Homosek (liwâth dan musâhaqah) adalah isu terkini yang sudah direspons oleh Aceh beberapa tahun lalu. MK tidak mengabulkan upaya kriminalisasi LGBT dengan alasan bukan merupakan kewenangan MK melegislasi sebuah peraturan. ${ }^{29}$

Jika dilihat dari hierarki dan klasifikasi sanksi, maka Qanun Jinayat Aceh menetapkan

${ }^{26}$ Pasal 284 Ayat (1) huruf a dan b KUHP menyatakan bahwa gendak (overspel) atau perzinahan diancam dengan penjara paling lama 9 (Sembilan) bulan. Zina dalam pasal tersebut adalah perbuatan seorangatau lebih perempuan atau laki-laki yang salah satunya telah diikat oleh sebuah perkawinan dengan orang lain. Definisi demikian sebenarnya lebih dekat dengan istilah 'selingkuh' atau 'perselingkuhan'. Selain keadaan demikian, zina dalam pasal tersebut baru dapat ditindaklanjuti jika ada pengaduan dari istri atau suami yang merasa dikhianati atau tercemar. Hal ini berbeda sama sekali dengan Aceh yang Qanun Jinayatnya tidak menjadikan delik zina sebagai delik aduan dan tidak pula mensyaratkan salah satu dari penzina adalah istri atau suami orang lain. Artinya, setiap orang yang melakukan hubungan intim meski tanpa ikatan perkawinan dianggap telah melakukan delik (jarimah) zina dan diancam dengan 100 kali cambuk (sanksi tunggal). Bandingkan KUHP Pasal 284 Ayat (1) huruf a dan b dan Pasal 33 Ayat (1) Qanun Aceh Nomor 6 Tahun 2014 tentang Hukum Jinayat.

${ }^{27}$ Dulu hanya ada tiga jarîmah yang masing-masing memiliki Qanunnya sendiri, yaitu khamr (minum minuman keras), maisir (judi), dan khalwat (berduaan dengan lawan jenis yang bukan mahram). Kini ditambah dengan ikhtilâth (bermesraan antara dua orang berlainan jenis yang bukan suami-istri), zina, pelecehan seksual, pemerkosaan, qadzaf (menuduh orang melakukan zina tanpa dapat mengajukan paling kurang empat saksi), liwâth (homoseksualitas), dan musâhaqah (lesbian). Lihat "Menggugat Qanun Jinayat," dalam http://icjr.or.id/menggugat-Qanun-jinayat/, Akses pada 25 Februari 2018.

${ }^{28}$ Ali Geno Berutu menyimpulkan bahwa Qanun Aceh Nomor 6 Tahun 2014 merupakan revisi yang menutupi kekurangan pada Qanun Qanun sebelumnya. Lihat Ali Geno Berutu, "Pengaturan Tindak Pidana dalam Qanun Aceh: Komparasi Antara Qanun Nomor 12, 13, 14 Tahun 2003", dalam Jurnal Mazahib, Vol. XVI, Nomor 2, 2017, h. 105.

${ }^{29}$ Lihat Putusan Nomor 46/PUU-XIV/2016, h. 1-467. 
sanksi sebagai berikut. ${ }^{30}$ Pertama, $\underline{\text { hudûd} . ~} \underline{H} u d u ̂ d$ berbentuk cambuk dan merupakan hukuman

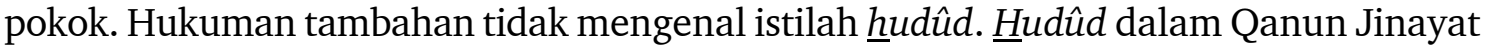
Aceh dan ilmu hukum pidana Islam (fiqh jinâyat) dipandang sebagai sanksi terberat dan serius. Perbuatan yang diancam dengan hukuman ini tergolong ke dalam serious crime yang harus ditangani secara serius pula. Kata atau istilah $\underline{h} u d \hat{u} d$ kerap muncul dalam ilmu fiqh. Itu artinya, hudûd juga dapat dikategorikan sebagai hasil ijtihâd manusia. Oleh karenanya, hudûd sangat berpeluang dipahami secara berbeda karena dapat pula dipengaruhi berbagai faktor termasuk non-hukum yang justru berperan siginifikan dalam membentuk paradigma $\underline{h} u d u ̂ d$ itu sendiri, seperti sosial-budaya dan perkembangan zaman. ${ }^{31}$ Kedua, ta'zîr. Pemahaman tentang 'uqûbât ta'zîr dibagi dua, yaitu 'uqûbât ta'zîr utama dan 'uqûbât ta'zîr tambahan. Untuk 'uqûbât ta'zîr utama terdiri dari cambuk, denda, penjara, dan restitusi. Sedangkan'uqûbât ta'zîr tambahan terdiri dari pembinaan oleh negara, restitusi oleh orang tua/wali, pengembalian kepada orang tua/wali, pemutusan perkawinan, pencabutan izin dan pencabutan hak, perampasan barang-barang tertentu, dan kerja sosial.

Ada yang menarik dari Qanun Jinayat Aceh yang terakhir ini, yaitu adanya pembaruan susunan sanksi hingga terlihat lebih rapi dan konsisten. Selain disusun secara hierarkis, sanksi-sanksi itu juga disusun dengan pola yang unik. Sebagai contoh perhatikan bunyi Pasal 25 Ayat (1) berikut, "setiap Orang yang dengan sengaja melakukan Jarîmah Ikhtilâth, diancam dengan 'uqûbât cambuk paling banyak 30 (tiga puluh) kali atau denda paling banyak 300 (tiga ratus) gram emas murni atau penjara paling lama 30 (tiga puluh) bulan."

Bunyi salah satu pasal dalam Qanun Jinayat Aceh di atas memberikan satu pemahaman mengenai pola sanksi dalam Qanun tersebut. Pasal di atas secara tidak langsung hendak mengatakan bahwa 1 kali cambuk sama dengan 1 bulan penjara dan setara dengan 10 gram emas murni. Pola ini berlaku konsisten dan menjadi unik serta baru dalam sistem pemidanaan di negara Indonesia. Pola ini hanya berlaku dalam hal suatu sanksi diklasifikasikan sebagai ta'zîr, bukan hudûd. ${ }^{32}$ Dapat dipahami di sini ialah, klasifikasi sanksi dalam Qanun Jinayat

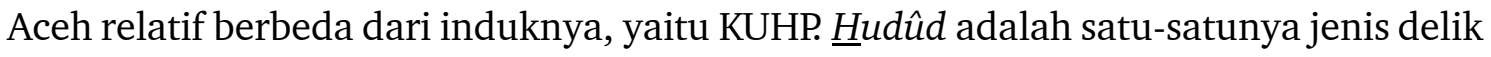
dan sanksi yang tidak ada di KUHP maupun RKUHP. Sedangkan ta'zîr jika dilihat dari bentuknya ada banyak kesamaan.

${ }^{30}$ Lihat Pasal 4 Qanun Aceh Nomor 6 Tahun 2014 tentang Hukum Jinayat. Lembaran Aceh Tahun 2016 Nomor 7.

${ }^{31}$ Aharis Mabrur, Rusjdi Ali Muhammad, dan Mohd. Din, "Konsepsi Pidana Hudud dalam Qanun Jinayat Aceh-Indonesia dan Brunei Darussalam," dalam Kanun Jurnal Hukum, Vol. 19, No. 1, April, 2017, h. 24.

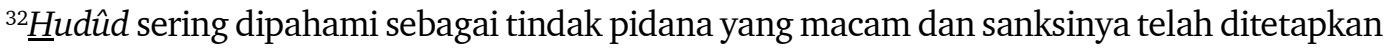
oleh Allah dan rasul-Nya. Definisi demikian berimplikasi pada sebuah penalaran bahwa hudûd sama dengan ibadah. Kreasi terhadapnya justru dianggap bidah. Mungkin definisi seperti inilah yang mempengaruhi perumusan sanksi hudud dan ta'zir sekaligus dalam Qanun Jinayat Aceh. Lihat Makhrus Munajat, Dekonstruksi Hukum Pidana Islam (Yogyakarta: Logung Pustaka, 2004), h. 95 . 
Hukum Jinayat pada dasarnya mengenal hukuman ('uqûbât) mati. Sebagian pakar malah menyebut rajam sebagai bagian dari teknik penghukuman yang dikenal dalam Islam, yaitu berlaku bagi pelaku zina yang sudah menikah (muhshan). Namun, Qanun Jinayat Aceh tidak mengadopsi hukuman demikian mengingat perkembangan zaman dan secara teoritis memang terdapat perdebatan yang sengit. Perlindungan HAM adalah satu alasan di antara banyak alasan lainnya. Sementara pidana penjara, bentuk sanksi ini juga dikenal dalam Qanun Jinayat Aceh, tepatnya dalam klasifikasi ta'zîr. Dalam sanksi ta'zîr, hanya penjara yang dikenal, sedangkan yang serupa dengannya, yakni pidana kurungan, tidak dikenal sama sekali. Meski begitu, pidana kurungan sejatinya adalah sama dengan pidana penjara. Keduanya dibedakan dari sisi bobot di mana penjara lebih lama masa tahanannya (sampai seumur hidup) sedangkan pidana kurungan paling lama hanya 1 (satu) tahun 4 (empat) bulan. Kewajiban kerja dalam dua bentuk hukuman ini juga berbeda dari sisi bobotnya. Terakhir, kedua istilah ini dimasukkan dalam KUHP karena KUHP mengenal istilah pelanggaran yang kurungan adalah di antara sanksinya. Sedangkan penjara, ia berlaku terhadap tindak pidana, bukan pelanggaran. ${ }^{33}$ Klasifikasi delik (jarîmah) demikian tidak dikenal dalam Qanun Jinayat Aceh sehingga Qanun hanya mengenal istilah pidana penjara.

Selanjutnya adalah denda. Pidana denda dalam Qanun Jinayat juga termasuk pidana ('uqûbât) ta'zîr utama. Pola denda dalam Qanun Jinayat Aceh ini disesuaikan dengan 'uqûbât cambuk atau penjara yang mestinya dijatuhi pada pelaku jarîmah. Adapun pidana tutupan, Qanun Jinayat Aceh tidak mengenal bentuk sanksi ini. Pidana tutupan itu sendiri merupakan pidana yang pelakunya biasa didorong oleh tujuan tertentu dan berpangkal dari ideologi atau paham yang dianutnya. Pidana tutupan ini berbeda dengan kurungan maupun penjara karena pelaku ditahan di dalam rumah tutupan. Pidana tutupan tentu lebih baik dibanding pidana penjara.

Untuk pidana tambahan, secara umum ia sepadan dengan pidana ta'zîr tambahan. 'Uqûbât ta'zîr tambahan bahkan lebih banyak bentuknya dibanding dengan pidana tambahan dalam KUHP. Perbedaan sanksi sebagaimana diterangkan di atas berdampak pada tujuan pemidanaan. Terlihat bahwa dalam Qanun Jinayat Aceh masih mempertahankan sanksisanksi yang secara teks ada dalam ayat-ayat al-Qur'an maupun Sunah Nabi. Mengambil secara utuh apa yang tertulis jelas dalam teks nash menjadi pembeda yang khas antara KUHP dan Qanun. Di sini, tujuan pemidanaan identik dengan ibadah yang pelaksanaannya harus diterima apa adanya. Ada dimensi akhirat di mana hukuman bukan sekadar untuk memperbaiki seseorang di dunia, tapi juga untuk membersihkannya dari dosa yang telah diperbuatnya. Perbedaan-perbedaan semacam inilah yang semestinya menjadi perhatian lebih dan menjadi kajian yang lebih mendalam. Pada tataran berikutnya, hasil dari penelitianpenelitian serius di bidang ini tentu menjadi masukan, baik bagi KUHP dan Undang-Undang Pidana lainnya maupun bagi Qanun Jinayat Aceh itu sendiri.

${ }^{33}$ Lihat Kitab Undang-Undang Hukum Pidana Pasal 12, 14, 18, 18 Ayat (3), 19 ayat (2) dan Pasal 30 Ayat (2). 
Di samping itu ada Qanun tentang hukum acara jinayat yang menjadi acuan dalam penegakan hukum jinayat itu sendiri. Jadi, berbicara Qanun atau hukum jinayat di Aceh tidak bisa dilepaskan dari Qanun Aceh Nomor 7 Tahun 2013 tentang Hukum Acara Jinayat dan Qanun Aceh Nomor 6 tahun 2014 tentang Hukum Jinayat. Qanun Hukum Jinayat Aceh merupakan bagian dari Qanun Aceh yang substansinya berisikan tentang jarîmah (delik/tindak pidana) dan 'uqûbât (pidana, sanksi, atau hukuman). ${ }^{34}$ Dengan begitu, Qanun Acara Jinayat atau Hukum Acara Jinayat merupakan Qanun Aceh yang isinya berbicara tentang bagaimana menegakkan hukum jinayat atau Qanun Jinayat, yaitu Qanun yang substansinya berbicara berkenaan dengan kebenaran materil dari suatu perkara jinayat.

Hukum acara jinayat saja belum cukup untuk kemudian perkara jinayat dapat dilaksanakan. Sekurangnya ada satu lagi peraturan yang di sini hanya akan disebut tanpa diulas lebih rinci. Peraturan itu adalah Peraturan Gubenur Aceh Nomor 5 Tahun 2018 tentang Pelaksanaan Hukum Acara Jinayat (Pergub). Pergub ini lahir agar norma-norma dalam hukum acara Jinayat dapat dilaksanakan. Dengan begitu, tiga klasifikasi hukum telah terpenuhi dalam bidang jinayat, yakni Qanun Jinayat sebagai hukum materil, Qanun Acara Jinayat sebagai hukum formil, dan Pergub pelaksanaan acara Jinayat sebagai hukum pelaksanaannya. Ketiga peraturan ini penting dalam pelaksanaan hukum Jinayat di Aceh.

Secara historis, Qanun Acara Jinayat ini dibentuk karena Kitab Undang-Undang Hukum Acara Pidana (KUHAP) Indonesia tidak sepenuhnya dapat diandalkan. Ada prinsipprinsip beracara (misalnya) yang dianggap suci dan dipahami apa adanya di dalam hukum Islam, sedangkan Kitab Undang-Undang Hukum Acara Pidana (KUHAP) tidak bisa menerimanya. Sebaliknya juga berlaku demikian. Ada yang sangat prinsip menurut KUHAP tapi tidak begitu berarti dalam tradisi hukum Islam, sehingga problem ini harus direspons dengan melahirkan Qanun Acara Jinayat. Qanun Acara Jinayat Aceh secara umum memiliki banyak persamaan dengan KUHAP. Karena alasan itu, yang perlu disinggung sedikit di sini ialah hal-hal yang dirasa memiliki perbedaan mencolok. Tentang alat bukti misalnya.

Disadari bagaimana pengakuan terdakwa telah ditiadakan dari alat bukti karena rentan menimbulkan kesewenang-wenangan dalam penegakan hukum. Namun, pengakuan terdakwa itu kembali diakomodir oleh Qanun Acara Jinayat ${ }^{35}$ karena pemidanaan tidak sekadar penghukuman dalam Islam, juga merupakan jalan untuk bertobat. Ada teori jawabir ${ }^{36}$

${ }^{34}$ Lihat Pasal 1 Ayat (34) Qanun Aceh Nomor 7 Tahun 2013 Tentang Hukum Acara Jinayat. Lembaran Aceh Tahun 2013 Nomor 7.

${ }^{35}$ Pasal 181 menyebutkan alat bukti yang sah terdiri atas: keterangan saksi; keterangan ahli; barang bukti; surat; bukti elektronik; pengakuan terdakwa; dan keterangan terdakwa. Lihat Qanun Aceh Nomor 7 Tahun 2013 Tentang Hukum Acara Jinayat. Lembaran Aceh Tahun 2013 Nomor 7.

${ }^{36}$ Teori jawabir jika disepadankan dengan hukum konvensional mirip dengan teori absolut yang lebih menekankan aspek represif. Dulu, teori ini juga mengenal istilah penghapusan dosa. Tujuan pemidanaan semacam ini dipandang kuno namun sukar dihilangkan dalam hukum pidana. Lihat Andi Hamzah, Sistem Pidana dan Pemidanaan Indonesia: dari Retribusi ke Reformasi (Jakarta: Pradnya Paramita, 1986), h. 16. 
yang menjelaskan bahwa 'uqûbât dapat menghapus dosa pelaku jarîmah. Bahkan ada hadis yang menegaskan hal ini. Imam Muslim meriwayatkan:

... barangsiapa ada di antara kalian yang melanggarnya, maka ia akan terkena hukuman, dan hukuman (had/hudûd) itu akan menjadi kafarat (tebusan) baginya. Barangsiapa yang pelanggarannya ditutupi oleh Allah, maka urusannya itu tergantung kepada Allah. Apabila Allah berkehendak untuk menyiksanya, maka Dia akan menyiksanya. Apabila Allah berkehendakuntuk mengampuninya, maka Dia pastiakan mengampuninya (HR. Muslim). ${ }^{37}$

Juhaya S. Praja ${ }^{38}$ menyatakan bahwa jawabir merupakan suatu tujuan pemidanaan yang ditujukan untuk pembalasan. Dalam teori ini hukuman ('uqûbât) bisa menghapus dosa pelaku kejahatan (expiation). ${ }^{39}$ Karena alasan inilah mengapa pengakuan kembali dikenal yang sudah barang tentu bertentangan dengan semangat perlindungan HAM dalam $\mathrm{KUHAP}^{40} \mathrm{KUHAP}$ menyadari betapa pengakuan kerap menjadi sasaran bagi penegak hukum yang kurang profesional. Ketika Penyidik tidak dapat menggali alat bukti, maka tersangka/ terdakwa bisa saja diancam, dipukul, bahkan disiksa yang dengannya tersangka/terdakwa akan mengaku. Jadi, sebenarnya, menghapus 'pengakuan' dari alat bukti agar hak-hak tersangka/terdakwa untuk diam, hak tidak disiksa, dan hak-hak lainnya dapat dilindungi.

Semangat KUHAP dalam melindungi HAM ini selain karena amanah dari UUD 1945, ia juga didasari pada filosofi bahwa HAM bukan pemberian, melainkan sesuatu yang melekat sejak manusia itu ada. Karena HAM adalah miliki manusia semata-mata pemberian raja, masyarakat, atau Undang-Undang. ${ }^{41}$ Penulis melihat bahwa pengakuan yang dihapuskan dari alat bukti bukanlah untuk mengebiri hak tersangka/terdakwa. Justru, semangatnya adalah untuk melindungi tersangka/terdakwa dari kesewenang-wenangan penegak hukum. ${ }^{42}$ Tersangka/terdakwa tetap boleh mengaku, tapi pengakuan itu masuk menjadi keterangannya semata. Apapun bunyi keterangan itu, maka ia adalah alat bukti. Sedangkan 'pengakuan', ia hanya menjerat tersangka/terdakwa dalam satu kemungkinan, yaitu bersalah dan kemudian dipidana. Di sinilah Qanun Acara Jinayat Aceh dapat disebut mundur. Sekalipun pengakuan

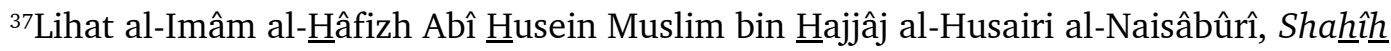
Muslim (Riyadh: Dâr al-Thaibah, 2006), h. 817.

${ }^{38}$ Juahaya S. Praja, Teori Hukum dan Aplikasinya (Bandung: Pustaka Setia, 2011), h. 83-84.

${ }^{39}$ Abdurrahmân al-Mâliki dan Ahmad al-Daur, Sistem Sanksi dan Hukum Pembuktian dalam Islam, terj. Syamsuddin Ramdlan (Jakarta: Pustaka Thariqul Izzah, 2004), h. 6.

${ }^{40}$ Dalam KUHAP terdapat alat-alat bukti: a. keterangan saksi; b. keterangan ahli; c. surat; d. petunjuk; e. keterangan terdakwa. Lihat Pasal 184 Ayat 1, Undang-Undang Nomor 8 Tahun 1981. Lembaran Negara Republik Indonesia Tahun 1981 Nomor 76.

${ }^{41}$ Yuli Asmara Triputra, "Implementasi Nilai-Nilai Hak Asasi Manusia Global ke dalam Sistem Hukum Indonesia yang Berlandaskan Pancasila," dalam IUS QUIA IUSTUM, No. 2, Vol. 24, April 2017, h. 282.

${ }^{42} \mathrm{Di}$ antara prinsip-prinsip HAM adalah interdefendance dan saling terkait. Prinsip ini menegaskan bahwa pemenuhan hak sering kali bergantung pada pemenuhan hak lainnya. Hal ini juga berarti, pengabaian suatu hak akan berimbas pada pengabaian hak-hak lainnya. Ibid, h. 285. 
atas paksaan tidak dapat diterima dalam acara jinayat, namun keterpaksaan atau di bawah ancaman itu sukar untuk dibilang 'tiada'. Semangat untuk mempertahankan dan mendorong seseorang mengakui dosanya, haruslah diimbangi dengan jaminan bagi tersangka/terdakwa dari ancaman, pukulan, dan/atau siksaan para penegak hukum atau bahkan masyarakat.

Meski demikian, pandangan lain datang dari Aharis Mabrur, Rusjdi Ali Muhammad, Mohd. Din. Menurut mereka, pembuktian hudud di mana Hakim dapat menjatuhkan 'uqûbât $\underline{h} u d u ̂ d$ atas dasar pengakuan semata (minta dihukum) sekaligus dapat pula dibatalkan apabila yang bersangkutan mencabut pengakuannya adalah suatu yang unik. Bahkan, bagi mereka, hal ini merupakan hal baru dalam konteks pembuktian hukum pidana di Indonesia. ${ }^{43}$ Pandangan ini kontras dengan kenyataan bahwa pengakuan adalah jenis alat bukti yang telah lama ditinggalkan. Namun demikian, penulis sepakat bahwa pengakuan dalam pembuktian perkara jinâyât menyiratkan eksistensi dimensi ukhrawi/ibadah (penebusan dosa) sebagaimana konsep dasar $\underline{h} u d u \hat{d}$. Penulis juga sepakat bahwa penerimaan hasil tes DNA sebagai pengganti empat orang saksi dalam kasus pembuktian zina tertentu merupakan terobosan baru. ${ }^{44}$

Selain itu, dalam Qanun Acara Jinayat ada pula pengecualian, yaitu dalam perkara zina. Jika semua kejahatan (jarîmah) harus memiliki dua alat bukti yang dengannya hakim memperoleh keyakinan, maka dalam perkara zina harus mendatangkan 4 orang saksi. Saksi di sini ialah orang yang mampu dan dapat memberikan keterangan untuk kepentingan penyidikan, penuntutan dan peradilan tentang suatu perkara pidana yang ia dengar sendiri, ia lihat sendiri dan ia alami sendiri (Pasal 1 Ayat 34). Jika tidak dapat menghadirkan 4 orang saksi, maka pelapor bisa saja dituntut kembali dengan pasal qadzaf (menuduh orang lain berzina).

Secara prinsip, ada beberapa prinsip dalam KUHAP yang harus diikuti oleh Qanun Acara Jinayat sebagai hukum yang berada di bawahnya. Prinsip-prinsip itu ialah: ${ }^{45}$

1. Asas persamaan di muka hukum. Asas ini juga dipegang dalam proses penegakan hukum Jinayat. Qanun Acara Jinayat Aceh dalam menangani delik-delik syariat harus berpedoman pada prinsip persamaan di muka hukum. Prinsip ini mengharuskan semua orang diperlakukan secara sama di hadapan hukum. ${ }^{46}$ Catatannya, ketika pelaku adalah non-Muslim,

${ }^{43}$ Aharis Mabrur, Rusjdi Ali Muhammad, dan Mohd. Din, Konsepsi Pidana Hudud dalam Qanun Jinayat Aceh-Indonesia, h. 26.

${ }^{44}$ Ibid.

${ }^{45} \mathrm{Al}-Y a s a$ Abu Bakar dan Marah Halim, Hukum Pidana Islam di Provinsi Nanggroe Aceh Darussalam (Banda Aceh: Dinas Syari'at Islam Provinsi NAD), h. 118-124.

${ }^{46}$ Prinsip persamaan di muka hukum ini menjadi konsideran Qanun Acara Jinayat Aceh. Pada bagian menimbang huruf $\mathrm{b}$ Qanun tersebut dijelaskan bahwa Aceh sebagai bagian dari Negara Kesatuan Republik Indonesia diberikan Keistimewaan dan Otonomi khusus, salah satunya kewenangan untuk melaksanakan syariat Islam, dengan menjunjung tinggi kepastian hukum, keadilan dan kesamaan di depan hukum. 
Qanun Jinayat Aceh membedakan perlakuannya. Ini cenderung tidak equal dan bertentangan dengan prinsip HAM. ${ }^{47}$

2. Asas legalitas. Selain karena Indonesia merupakan negara yang dalam sistem hukumnya condong kepada civil law, hukum Islam juga mengenal prinsip legalitas ini sejak lama. Maka, prinsip legalitas ini juga ada dalam Qanun Jinayat Aceh dan Qanun Acaranya. ${ }^{48}$ Meskipun dalam al-Qur'an dan Sunah suatu perbuatan telah dilarang, ia tidak dapat ditegakkan lantaran Qanun tidak mengaturnya. Contohnya adalah qishâsh dan rajam. Selain delik yang diancam dengan dua sanksi tersebut, jenis sanksi qishâsh dan rajam juga tidak dikenal dalam Qanun Jinayat. Berdasarkan prinsip ini, maka seorang yang berzina sekalipun telah menikah, hanya dapat dijatuhi sanksi zina dengan pemberatan semata, bukan rajam.

3. Asas praduga tidak bersalah. Prinsip praduga tidak bersalah ini bahkan di beberapa jarîmah sangat dipegang teguh. Misalnya dalam perkara zina. Seseorang yang diduga berbuat zina namun tidak terdapat 4 orang saksi, maka ia tidak dapat dijatuhi pidana cambuk sekalipun secara umum dua alat bukti sudah cukup bagi Hakim untuk memperoleh keyakinan. Namun, dalam kasus zina, orang yang menuduh tanpa bukti bahkan dapat dipidana balik dengan cambuk 80 (delapan puluh) kali.

4. Asas ganti kerugian dan rehabilitasi. Selain karena seseorang harus diduga tidak bersalah hingga ada putusan Hakim yang menyatakan dirinya bersalah, maka jika terbukti tidak bersalah seseorang harus mendapat ganti rugi dan rehabilitasi. Qanun Jinayat juga mengatur hal yang sama agar terpenuhinya hak seseorang untuk dianggap tidak bersalah hingga ada putusan Hakim yang menyatakan sebaliknya. ${ }^{49}$

5. Asas peradilan cepat, sederhana, biaya ringan, bebas, jujur, dan tidak memihak. Dalam proses persidangan, demi tercapainya keadilan, maka akses menuju ke sana harus berdasarkan prinsip tersebut. Jika KUHAP bahkan mengharuskan tersangka atau terdakwa didampingi oleh pengacara yang ia pilih sendiri atau disediakan oleh negara, Qanun juga mengakomodir hal-hal semacam ini. Hal ini tidak lain agar peradilan yang berbiaya ringan dapat terwujud.

6. Asas memperoleh bantuan hukum. Tersangka dan terdakwa wajib memperoleh bantuan

${ }^{47}$ Equality atau persamaan meletakkan semua orang pada posisi yang sama. Prinsip ini menegaskan bahwa dalam situasi yang sama seseorang harus diperlakukan dengan cara yang sama pula. Namun, dalam prinsip ini harus ada tindakan afirmasi (affirmative action) agar seseorang dapat mencapai kesetaraan lebih cepat karena pada awalnya ia dipandang tidak setara. Catatannya, jika keadaannya sudah setara, tindakan afirmasi ini harus dihapuskan. Yuli Asmara Triputra, Implementasi, h. 284.

${ }^{48}$ Pasal 2 hurus a Qanun Aceh Nomor 7 Tahun 2013 tentang Hukum Acara Jinayat Lembaran Aceh Tahun 2013 Nomor 7, menyebutkan bahwa penyelenggaraan hukum acara Jinayat dilaksanakan berdasarkan asaslegalitas.

${ }^{49}$ Prinsip ini tertuang dalam Pasal 2 huruf e Qanun Aceh Nomor 7 Tahun 2013 tentang Hukum Acara Jinayat. Lembaran Aceh Tahun 2013 Nomor 7. 
hukum. Jika ia menolak, maka penolakan itu hanya boleh pada kejahatan ringan. Untuk kejahatan yang diancam dengan pidana penjara 5 (lima) tahun ke atas, tersangka dan terdakwa wajib didampingi pengacara. Qanun Acara Jinayat bahkan menegaskan bahwa hak memperoleh bantuan hukum dapat diperoleh di setiap proses pemeriksaan. ${ }^{50}$

7. Asas pengakuan hak-hak tersangka. Prinsip ketujuh ini menjadi garansi bagi tersangka dan terdakwa dalam membela diri dan membela harkat martabatnya sebagai manusia. Hal itu diatur dalam KUHAP dan dalam Pasal 56 Qanun Aceh Nomor 7 Tahun 2013 tentang Hukum Acara Jinayat.

8. Asas hadirnya terdakwa, bahwa pengadilan hanya memeriksa perkara dengan kehadiran terdakwa. Prinsip ini dijadikan dasar dalam KUHAP guna menjamin beberapa prinsip yang telah disinggung di awal dapat terpenuhi. Jika terdakwa tidak hadir dan proses pengadilan tetap dilakukan, maka terdakwa akan kehilangan beberap haknya. Ini tidak boleh terjadi demi keadilan. Qanun Acara Jinayat juga berdiri di atas prinsip demikian.

9. Asas pengadilan yang terbuka untuk umum. Prinsip ini juga diakui dalam Qanun Acara Jinayat. Dalam Qanun Acara Jinayat bahkan ada pula prinsip pembelajaran kepada masyarakat (tadabbur). Dengan pengadilan yang terbuka untuk umum ini, prinsip pembelajaran kepada masyarakat dapat pula tercapai. Bukan hanya ketika pelaksanaan sanksi, mulai dari dirumuskannya norma-norma hukum jinayat itu harusnya dapat mempengaruhi orang untuk tidak berbuat kejahatan (jarîmah). ${ }^{51}$

Meski sedemikian relevannya prinsip-prinsip Qanun Acara Jinayat terhadap KUHAP, tetap ada beberapa hal yang sengaja dibedakan karena dianggap lebih baik dan merupakan kebolehan karena Qanun tentang syariat Islam (termasuk Qanun Acara Jinayat) dipandang sebagai hukum khusus dan hanya berlaku di Aceh. Sebagian lagi dibedakan karena dipandang lebih mumpuni dan lebih sejalan dengan prinsip-prinsip di atas.

Jika dilihat dari kelahirannya, hukum jinayat telah lebih dulu ada dibanding hukum acara jinayat. Sebelum memiliki hukum acara sendiri, Qanun Jinayat Aceh ditegakkan dengan mengikuti ketentuan dalam KUHAP. Tapi, menggunakan KUHAP dalam hal ini dipandang tidak cocok dan sukar menerapkannya. Karena alasan itu, maka dibentuklah Qanun Hukum Acara Jinayat agar Hukum Jinayat yang sudah diformalkan itu dapat tegak dengan baik. Setelah Qanun Hukum Acara Jinayat Aceh lahir, barulah giliran hukum materil, yaitu Hukum Jinayat Aceh direvisi dan disempurnakan ke dalam Qanun Aceh Nomor 6 Tahun 2014 Tentang Hukum Jinayat.

Qanun Jinayat Aceh dan hukum acaranya kendati merupakan bagian dari sistem

${ }^{50}$ Pasal 56 huruf f, g, dan h Qanun Aceh Nomor 7 Tahun 2013 tentang Hukum Acara Jinayat. Lembaran Aceh Tahun 2013 Nomor 7.

${ }^{51}$ Lihat Pasal 56 Qanun Aceh Nomor 7 Tahun 2013 tentang Hukum Acara Jinayat. Lembaran Aceh Tahun 2013 Nomor 7. 
hukum pidana Indonesia, namun faktanya mengatur banyak hal yang berbeda dan berpotensi bahkan sudah menabrak norma di atasnya. Sampai di sini dimaklumi mengapa ada sekian banyak agenda untuk membatalkan Qanun Jinayat. Institut for Criminal Justice Reform (ICJR) adalah lembaga yang kerap memberikan respons tajam dan fokus terhadap isu pelanggaran HAM yang merupakan implikasi langsung dari penerapan Qanun Jinayat Aceh. Selain melanggar HAM, secara yuridis norma-norma dalam Qanun Jinayat juga bertabrakan dengan norma-norma di atasnya. ${ }^{52}$ Setidaknya ada 10 Undang-Undang yang ditabrak oleh Qanun Jinayat Aceh versi ICJR: ${ }^{53}$

1. Kitab Undang-Undang Hukum Pidana;

2. Undang-Undang Nomor 39 Tahun 1999 tentang Hak Asasi Manusia;

3. International Convenant on Civil and Political Rights (Konvenan Internasional tentang Hak-Hak Sipil dan Politik) yang diratifikasi melalui Undang-Undang Nomor 12 Tahun 2005;

4. Convention Against Torture and Other Cruel, Inhuman or Degrading Treatment or Punishment (Konvensi Menentang Penyiksaan dan Perlakuan atau Penghukuman Lain yang Kejam, Tidak Manusiawi, atau Merendahkan Martabat Manusia) yang diratifikasi melalui Undang-Undang Nomor 5 Tahun 1998;

5. Undang-Undang Nomor 12 Tahun 2011 Tentang Pembentukan Peraturan Perundangundangan.

6. Undang-Undang Nomor 11 Tahun 2012 tentang Sistem Peradilan Pidana Anak;

7. Undang-Undang Nomor 23 Tahun 2002 tentang Perlindungan Anak, sebagaimana telah diubah melalui Undang-Undang Nomor 35 Tahun 2004;

8. Undang-Undang Nomor 8 Tahun 1981 tentang Hukum Acara Pidana;

9. Undang-Undang Nomor 48 Tahun 2009 Tentang Kekuasaan Kehakiman; dan

10. Konvensi Anti Diskriminasi terhadap Perempuan (The Convention on the Elimination of all forms of Discrimination Against Women) yang diratifikasi melalui UU Nomor 7 Tahun 1984.

\footnotetext{
${ }^{52}$ Karena alasan-alasan menabrak HAM dan menabrak norma dan prinsip yang tertuang dalam konvensi dan Undang-Undang yang lebih tinggi, ICJR akhirnya menggunakan hak mengajukan uji materi Qanun ke MA 2015 silam. Permohonan mereka tidak dikabulkan karena dipandang tidak mewakili masyarakat Aceh. Pihak ICJR berdalih bahwa jika masyarakat Aceh secara individu ataupun kelompok yang mengajukannya, maka mereka rentan dicap kafir karena telah menggugat syari'at Islam. Itu sebabnya ICJR yang berinisiatif mengajukan hak uji materil itu. Lihat "Menggugat Qanun Jinayat," dalam http://icjr.or.id/menggugat-Qanun-jinayat/, Akses pada 25 Februari 2018.

${ }^{53}$ Lihat "ICJR dan Solidaritas Perempuan Ajukan Hak Uji Materil Qanun Jinayat Aceh ke Mahkamah Agung," dalam http://icjror.id/icjr-dan-solidaritas-perempuan-ajukan-hak-uji-materilQanun-jinayat-aceh-ke-mahkamah-agung/, Akses pada 25 Februari 2018.
} 
Sampai di sini, polemik pemidanaan dalam Qanun Jinayat Aceh tentu menimbulkan satu masalah baru. Pro-kontra terhadapnya sudah barang tentu ada. Namun, yang perlu digarisbawahi di sini ialah semangat pembaruan yang kian terasa. Meski dalam beberapa hal sebenarnya Qanun Jinayat seperti berjalan ke belakang, tapi ia mencoba keluar dari hukum kolonial yang kian membelenggu Indonesia. Dalam hubungannya sebagai sub dari sistem hukum pidana Indonesia, Qanun Jinayat Aceh harus terus diupayakan sejalan dengan norma di atasnya. Tidak hanya itu, Qanun Jinayat Aceh harusnya juga menjadi stimulus bagi pembaruan dan pembangunan hukum pidana nasional.

\section{Penutup}

Ulasan di atas mengantarkan pada kesimpulan bahwa norma dan prinsip abstrak yang dianut oleh Qanun Jinayat Aceh dan hukum acaranya memiliki perbedaan yang menjadikannya unik sekaligus berpotensi menabrak KUHP dan Undang-Undang Pidana di atasnya. Keunikan dimaksud dapat dilihat dari pola sanksi yang ditetapkan secara konsisten dalam Qanun Jinayat. Qanun ini menyatakan bahwa Satu (1) kali cambuk setara dengan satu (1) bulan penjara dan sama dengan sepuluh (10) gram emas murni. Pola demikian tidak ditemukan dalam KUHP dan RKUHP Indonesia. Tentu hal ini patut dijadikan stimulus bagi pembaruan hukum pidana nasional sebagaimana telah disinggung dalam pembahasan.

Di samping itu, perbedaan-perbedaan yang menjadikan Qanun Jinayat Aceh dan hukum acaranya unik itu juga memiliki potensi bahkan secara nyata berseberangan dengan KUHP dan Undang-Undang di atasnya. Sebagai contoh adalah pengakuan terdakwa yang ada dalam Qanun Acara Jinayat. KUHAP dan hukum acara di mana pun telah menghapus alat bukti yang satu ini demi menjaga Hak Asasi Manusia, atau hukuman cambuk dengan pelaksanaannya sejauh ini juga masih perlu dibahas lebih jauh. Ada banyak hal yang patut dikritisi sekaligus diapresiasi. Untuk itu, reorientasi pemidanaan di Aceh patut menjadi agenda lain demi terintegrasinya Aceh ke dalam sistem hukum pidana nasional. Keistimewaan tidak harus dimaknai sebagai pembeda, melainkan penguat bagi kesatuan sistem hukum di mana Qanun Jinayat Aceh merupakan bagian dari sub-sistem hukum pidana dimaksud.

Hukum syariat dalam hal ini hukum jinayat merupakan salah satu bentuk hukum nasional yang bersifat lokal yang berlaku di Aceh. Pemberlakuan ini didasarkan kepada Undang-Undang yang berlaku secara sah dan resmi dalam sistem hukum Indonesia. Pandangan ini menepis anggapan bahwa pemberlakuan hukum syariat hanya bersifat sepihak karena realitas yang ada menyatakan sebaliknya. Sebagai bukti adalah wujudnya UU No. 44/1999 tentang Keistimewaan Aceh, UU No. 18/2001 tentang otonomi khusus, UU No. 11/2006 tentang Pemerintahan Aceh.

Tulisan ini merupakan suatu eksplorasi atas perkembangan hukum di Indonesia karena itu bagi para pemikir dan tokoh akademisi agar terus mengikuti perkembangan hukum yang ada agar dapat berperan aktif mengembangan pemikiran hukum pada masa 
depan. Syariat Islam sebagai agama tentu telah dilaksanakan sedemikian rupa dalam kehidupan masyarakat. Namun syariat Islam dipahami sebagai hukum dalam sistem hukum negara tentu memerlukan waktu dalam pelaksanaannya. Kepada peneliti agar dapat melanjutkan penelitiannya di Aceh baik syariat Islam, Qanun jinayat atau hal lainnya yang relevan dan menarik, di mana hukum nasional Indonesia telah memberi ruang untuk terlaksananya hukum Islam khususnya hukum jinayat dalam kehidupan masyarakat Aceh. Posisi hukum Jinayat di Aceh masih relevan untuk dikaji dan dikawal karenanya secara formal masih relatif baru karena itu diharapkan peran para peneliti akan memberi semangat baru bagi kesempurnaan pelaksanaannya. Kondisi ini semakin terarah dan kuat sekiranya para peneliti secara terus menerus memberikan kontribusi nyata terhadap realitas kehidupan hukum dalam masyarakat Aceh.

Hukum negara adalah hukum yang lebih terjamin pelaksanaannya dan pengembangannya karena itu kekhawatiran terhadap pemberlakuan hukum jinayat di Aceh tidak pada tempatnya. Untuk itu agar praktisi hukum dapat memahami Qanun jinayat dalam sistem hukum nasional. Secara khusus, praktisi dengan pengalaman lapangan yang luas dan mendalam tentu memberikan sumbangsih dalam pengembangan hukum syariat ke depan dalam membangun cita hukum masyarakat dan negara. Kekhawatiran masyarakat di luar Aceh terhadap dampak negatif pelaksanaan syariat Islam tidak perlu ditanggapi secara berlebihan karena demikian menjadi pemicu untuk lurusnya penerapan syariat Islam. Karena penerapan syariat Islam di Aceh dijalankan secara seksama tanpa adanya contoh ideal yang patut ditiru melainkan berjalan secara pelan dan pasti dalam koridor hukum Negara Kesatuan Republik Indonesia.

\section{Pustaka Acuan}

Abbas, Syahrizal. Maqashid al-Syariah dalam Qanun Jinayah di Aceh. Banda Aceh: Dinas Syari'at Islam, 2015.

Abu Bakar, al-Yasa, dan Marah Halim. Hukum Pidana Islam di Provinsi Nanggroe Aceh Darussalam. Banda Aceh: Dinas Syari'at Islam Provinsi NAD.

Abubakar, Al Yasa dan Marahalim. Hukum Pidana Islam di Provinsi Nanggroe Aceh Darussalam. Banda Aceh: Dinas Syari'at Islam, 2006.

Al-Mâliki, 'Abdurrahmmân, dan Aḥmad al-Daur. Sistem Sanksi dan Hukum Pembuktian dalam Islam, terj. Syamsuddin Ramdlan. Jakarta: Pustaka Thariqul Izzah, 2004.

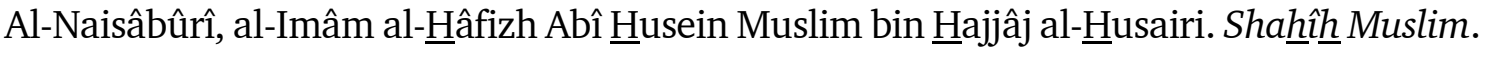
Riyadh: Dâr al-Thaibah, 2006.

Audah, Jasser. Membumikan Hukum Islam Melalui Maqashid Syariah, terj. Rosidin dan Ali Abd el-Mun'im. Bandung: Mizan, 2015.

Berutu, Ali Geno. "Pengaturan Tindak Pidana dalam Qanun Aceh: Komparasi Antara Qanun Nomor 12, 13, 14 Tahun 2003," dalam Jurnal Mazahib, Vol. XVI, Nomor 2, 2017. 
MIQOT Vol. XLII No. 2 Juli-Desember 2018

Danial. "Fikih Mazhab Iran dan Aceh: Analisis Konsep Pemidanaan dalam Hukum Pidana Iran dan Aceh." Yogyakarta: Sekolah Pascasarjana UGM, 2015.

Departemen Pendidikan dan Kebudayaan. Kamus Besar Bahasa Indonesia. Jakarta: Balai Pustaka, t.t.

Endrawati, Netti. "Sistem Hukum dan Pembangunan Hukum," dalam Wastu, Vol. Khusus, Desember 2007.

Gayo, Ahyar Ari. "Aspek Hukum Pelaksanaan Qanun Jinayat di Provinsi Aceh," dalam Jurnal Penelitian Hukum De Jure, Vol. 17, No. 2, Juni 2017.

Hamzah, Andi. Sistem Pidana dan Pemidanaan Indonesia: dari Retribusi ke Reformasi. Jakarta: Pradnya Paramita, 1986.

Khairil. Pidana Mati terhadap Penyalahguna Psikotropika dalam Perspektif Teori Pemidanaan Islam: Studi Terhadap UU No. 5 Tahu 1997 tentang Psikotropika. Banda Aceh: UIN ArRaniry, 2014.

Mabrur, Aharis, et al. "Konsepsi Pidana Hudud dalam Qanun Jinayat Aceh-Indonesia dan Brunei Darussalam," dalam Kanun Jurnal Hukum, Vol. 19, No. 1, April, 2017.

Moleong, Lexy J. Metodologi Penelitian Kualitatif. Bandung: Rosdakarya, 2000.

Munajat, Makhrus. Dekonstruksi Hukum Pidana Islam. Yogyakarta: Logung Pustaka, 2004.

Nurhardianto, Fajar. "Sistem Hukum dan Posisi Hukum Indonesia", dalam Jurnal TAPIs, Vol. 11. No. 1 Januari-Juni 2015.

Praja, Juahaya S. Teori Hukum dan Aplikasinya. Bandung: Pustaka Setia, 2011.

Qamar, Nurul. Perbandingan Sistem Hukum dan Peradilan. Makasar: Pustaka Refleksi, 2010.

Syahnan, Mhd. Contemporary Islamic Legal Discourse: A Study of Sayyid Quthb's Fi Zhilal al-Qur'an. Medan: IAIN Press, 2010.

Syahnan, Mhd. Hukum Islam dalam Bingkai Transdisipliner. Medan: Perdana Publishing, 2018.

Triputra, Yuli Asmara. "Implementasi Nilai-Nilai Hak Asasi Manusia Global ke dalam Sistem Hukum Indonesia yang Berlandaskan Pancasila," dalam IUS QUIA IUSTUM, No. 2, Vol. 24, April 2017.

Yunus, Mahmud. Kamus Arab-Indonesia. Jakarta: Hidakarya Agung, 1989.

Zainuddin, Muslim. Problematika Hukuman Cambuk di Aceh. Banda Aceh: Dinas Syari'at Islam, 2011.

"ICJR dan Solidaritas Perempuan Ajukan Hak Uji Materil Qanun Jinayat Aceh ke Mahkamah Agung," dalam http://icjr.or.id/icjr-dan-solidaritas-perempuan-ajukanhak-uji-materil-Qanun-jinayat-aceh-ke-mahkamah-agung/, Akses pada 25 Februari 2018.

"Menggugat Qanun Jinayat," dalam http://icjr.or.id/menggugat-Qanun-jinayat/, Akses pada 25 Februari 2018. 